\title{
Analisis Persepsi dan Ekspektasi Mahasiswa atas Kualitas Dosen Pembimbing Tesis di program Magister Akuntansi FEB Universitas Sam Ratulangi Manado
}

\author{
LINDA LAMBEY ${ }^{1}$, ROBERT LAMBEY ${ }^{2}$, LINTJE KALANGI ${ }^{3}$ \\ ${ }^{1,2,3}$ Program Magister Akuntansi, Fakultas Ekonomi dan Bisnis Universitas Sam Ratulangi \\ email: lindalambey@yahoo.com¹, robert_lambey@yahoo.com², lintje_kalangi@yahoo.com ${ }^{3}$
}

\begin{abstract}
One of the requirements to graduate from Magister of Accounting program at the Faculty of Business and Economics, Univevrsity of Sam Ratulangi Manado is to write thesis. Thesis supervisors are crucial for student's successful of their thesis completion. This study aims to analyse student's perceptions and expectations on their thesis supervision. This research contributes to practical and theoretical implications. In terms of practical implication, it is intended to help the management in providing advices and suggestions to thesis supervisors. Thus, thesis supervisors can provide their services and or supervisions in the ways to satisfy their students' expectations. The theoretical implication is to contribute perception and expectancy theories in the higher education setting between student and academic. This is a qualitative exploratory research. Data were collected by conducting in-depth interviews to 12 respondents who graduated from the program, observation and documentation. Data were analysed by content analysis. Findings suggested that supervisors are expected to be excellent in research methods, experienced and senior, have published their international publications, excellent in information technology, know the research topic, can give great directions towards their students, and can be thesis proofreaders. On the other hand, supervisors are perceived as qualified thesis supervisors if those academics can spend their time sufficiently with their students, have close and emotional relationships with their students, can explain, give directions and communicate effectively with their students and finally, they can write excellent research.
\end{abstract}

Keywords: Perception, expectancy, qualifications of thesis supervisors

\begin{abstract}
Abstrak. Salah satu syarat kelulusan mahasiswa program Magister Akuntansi (MAKSI) di Fakultas Ekonomi dan Bisnis Universitas Sam Ratulangi Manado adalah menyelesaikan tesis atau karya ilmiah akhir. Kualitas dosen pembimbing amat berperan terhadap keberhasilan penulisan tesis ini. Untuk itu, tujuan penelitian ini adalah untuk menganalisis persepsi dan ekspektasi mahasiswa terhadap kualitas dosen pembimbing tesis mereka. Penelitian ini diharapkan dapat memberikan kontribusi praktis bagi penyelenggara program untuk mengarahkan dosen dalam menyelenggarakan pembimbingan yang dapat memberikan kepuasan bagi para mahasiswa. Sedangkan manfaat teoritis dari penelitian ini adalah untuk memberikan kontribusi literature terhadap teori persepsi dan ekspektasi di dunia pendidikan tinggi. Penelitian ini dilakukan dengan menggunakan exploratory qualitative research dengan jumlah responden sebanyak 12 orang mahasiswa yang telah menyelesaikan studi mereka di program MAKSI ini. Data dianalisa dengan menggunakan content analysis dan dikumpulkan melalui in-depth interviews, observation dan document analysis. Hasil penelitian menunjukkan bahwa dosen pembimbing tesis dikatakan berkualitas jika dosen tersebut menguasai metode penelitian, dosen senior yang sudah berpengalaman, dosen yang sudah memiliki publikasi/jurnal internasional, dosen yang menguasai aplikasi komputer, dosen yang menguasai materi/topik tesis yang dibimbing, dosen yang dapat mengarahkan mahasiswa dan dosen yang memiliki ketelitian dalam membaca atau memeriksa tesis mahasiswa. Sedangkan persepsi mahasiswa atas kualitas dosen pembimbing yang diinginkan oleh mahasiswa adalah dosen yang dapat meluangkan waktu yang cukup untuk pembimbingan, dosen yang bisa memiliki kedekatan emosional dengan mahasiswa bimbingannya, dosen yang mampu menjelaskan, mengarahkan dan berkomunikasi dengan efektif dan dosen yang mampu membuat penelitian yang berkualitas.
\end{abstract}

Kata kunci: Persepsi, Ekspektasi, Kualitas Dosen Pembimbing Tesis.

\section{Latar Belakang Masalah dan Pertanyaan Riset}

Program Magister Akuntansi (MAKSI) Strata 2 Fakultas Ekonomi dan Bisnis Universitas Sam Ratulangi Manado didirikan berdasarkan ijin dari Departemen Pendidikan Nasional Direktorat Pendidikan Tinggi dengan nomor 2356/D/T/2009. Tujuan pendirian program ini adalah untuk memberikan pendidikan tinggi S2 bagi para lulusan strata satu dan juga bagi para pegawai negeri dan swasta. Program ini juga didirikan untuk mendukung pemerintah dalam mencerdaskan kehidupan bangsa sesuai dengan alinea ke 4 Pembukaan Undang-undang Dasar (UUD) 1945. 
Program MAKSI Unsrat mendapatkan akreditasi B sejak tanggal 12 September 2013 dengan masa berlaku 5 (lima) tahun. Konsentrasi yang ditawarkan adalah Akuntansi Sektor Publik. Program ini telah bekerja sama dengan Badan Pengawasan Keuangan dan Pembangunan (BPKP) Republik Indonesia yang menyalurkan beasiswa bagi para Aparatur Sipil Negara di bidang keuangan dan Aparat Pengawas Internal Pemerintah (APIP) Daerah di provinsi Sulawesi Utara.

Menurut data dari program MAKSI Unsrat, jumlah mahasiswa bertambah secara signifikan. Jumlah mahasiswa yang terdaftar adalah berjumlah kurang lebih 200 orang dibandingkan dengan pada tahun pertama yang hanya berjumlah sekitar 20 orang. Hal ini dapat menandakan bahwa program MAKSI ini diminati oleh para mahasiswa. Pihak pimpinan manajemen Fakultas dan program juga berkomitmen untuk meningkatkan kualitas dari program ini, dimana salah satu upaya peningkatan kualitas tersebut adalah menyangkut kualitas dosen dalam pembimbingan tesis atau karya akhir sebagai syarat mutlak kelulusan.

Dari observasi kami, kualitas dosen dalam memberikan bimbingan tesis kepada mahasiswa amat berpengaruh terhadap kepuasan mahasiswa dan merupakan salah satu faktor penentu kelulusan mahasiswa tersebut, baik dari segi waktu penyelesaian maupun kualitas hasil karya ilmiah tersebut. Kualitas dosen dalam memberikan bimbingan untuk menghasilkan karya ilmiah yang dapat memberikan nilai kelulusan dari mahasiswa yang bersangkutan dapat ditinjau dari: (1) penguasaan isi dan tekhnik tulisan oleh dosen, (2) waktu dan lamanya bimbingan diberikan oleh dosen, (3) kualitas bimbingan setiap pertemuan, (4) prilaku dari dosen tersebut. Oleh karena itu, penelitian ini dilakukan untuk menganalisis persepsi dan ekspektasi mahasiswa atas kualitas dosen pembimbing tesis mereka yang menentukan keberhasilan performance mahasiswa.

Implikasi praktik yang dapat diberikan oleh penelitian ini adalah untuk memberikan masukan bagi pihak manajemen dan para pembuat keputusan di program MAKSI secara khusus dan Fakultas secara umum. Sedangkan implikasi teoritis adalah untuk memberikan kontribusi teoritis bagi dunia literature di bidang Higher Education dan education management tentang kualitas dosen pembimbing berdasarkan persepsi dan ekpektasi dari mahasiswa itu sendiri. Keunggulan lainnya dari penelitian ini adalah digunakannya metode exploratory qualitative research untuk pelaksanaan riset ini. Selama ini, penelitian sejenis yang telah ada hanya menggunakan metode quantitative research dan pengumpulan data dilakukan dengan questionnaire. Dengan menggunakan metode exploratory qualitative research, penelitian diharapkan dapat menemukan dimensi-dimensi kualitas dosen yang belum pernah diperoleh dari penelitian sebelumnya, sehingga dapat memberikan kontribusi baru bagi dunia teoritis.

Berdasarkan pemaparan alasan diatas ini, maka perumusan masalah atau research questions untuk penelitian ini adalah sebagai berikut:

1. Bagaimana persepsi mahasiswa atas kualitas dosen pembimbing tesis mereka?

2. Apa dimensi-dimensi kualitas dosen pembimbing tesis yang diharapkan oleh mahasiswa? Berdasarkan research questions diatas, maka tujuan penelitian yang ingin dicapai adalah:

1. Untuk menginvestigasi persepsi mahasiswa atas kualitas dosen pembimbing tesis mereka.

2. Untuk menginvestigasi dan menganalisis dimensi-dimensi kualitas dosen pembimbing tesis yang diharapkan oleh mahasiswa.

\section{Conceptual Framework \\ Perception Theory}

Persepsi seseorang bersifat subjektif karena setiap manusia memiliki persepsi atau mental model yang berbeda satu sama lainnya (Mao \& Liu, 2008). Individual harus memiliki informasi yang banyak dan kompleks untuk memberikan respons dan berinteraksi dalam kehidupan mereka di dunia ini (Johnson-Laird, 1983a). Persepsi adalah cara berpikir strategis manusia (Malan, Erwee \& Rose, 2009).

Persepsi itu berperan penting dalam kehidupan seseorang karena merupakan persepsi tersebut merupakan mental model mereka dalam mengestimasi dan menorganisir kehidupan mereka di lingkungan yang kompleks di situasi apapun. Persepsi itu memiliki nilai dan realitas yang mengarahkan seseorang itu untuk berprilaku dan berinteraksi dengan alasan dan pilihan-pilihan mereka (Westbrook, 2006). Johnson-Laird (1983b) menekankan bahwa persepsi manusia itu berperan amat penting dalam pemahaman objek, kejadian-kejadian yang terjadi, keadaan dunia ini dan tindakan-tindakan sosial dan psikologis dalam kehidupan sehari-hari. Sifat alamiah persepsi itu memungkinkan manusia untuk membuat kesimpulan dan asumsi, untuk mengetahui dan memahami fenomena dan kejadian, untuk mengambil keputusan, untuk mengambil tindakan dan mengontrol pengimplementasian aktivitas (Borges \& Gilbert, 1999). 


\section{Expectancy Theory}

Teori ekspektasi dalam dunia literature dipelopori oleh Vroom pada tahun 1964. Vroom mengemukakan bahwa ekpektasi adalah probabilitas subjektif dari sebuah tindakan atau usaha (effort=e) yang menghasilkan suatu hasil atau kinerja (performance=p), sehingga diekspresikan sebagai e ->• p. Pada prakteknya, ekpektasi juga diukur sebagai sebuah persepsi akan suatu hubungan atau korelasi antara sebuah tindakan dan suatu hasil atau outcome. Lebih jauh lagi, ekpektasi diinterpretasikan sebagai suatu probabilitas subjektif dimana effort menghasilkan suatu hasil dari kinerja (outcome of performance) atau second-level outcome (o) yang diekspresikan sebagai as e $-\gg \bullet^{\circ} \mathrm{o}$ (Van Eerde \& Thierry, 1996).

Secara keseluruhan, model ekspektasi ini mendefinikan motivasi sebagai fungsi kombinasi dari variabel-variabel berikut: jika seseorang berusaha untuk melakukan tujuan tugas mereka maka usaha tersebut diyakini dapat menuju kesuksesan karena orang itu akan berusaha mencapai tujuan tersebut yang dapat memberikan reward kepadanya (Lawler \& Suttle, 1973). Lebih lanjut Lawler dan Suttle menyatakan bahwa prilaku ini diyakini merupakan kombinasi dari motivation dan ability. Sehingga persepsi dalam hal ini dapat didefinisikan sebagai suatu tindakan dan prilaku yang harus dilakukan supaya dapat mencapai kesuksesan kerja termasuk didalamnya kesuksesan studi.

\section{Persepsi dan Ekspektasi Mahasiswa atas Kualitas Dosen}

Seorang dosen harus memiliki dua kategori yaitu memiliki capability dan loyality, dimana dosen harus memiliki kemampuan dalam bidang ilmu yang menjadi keahliannya, memiliki kemampuan teoretis tentang mengajar yang baik, mulai dari perencanaan, implementasi sampai evaluasi termasuk didalamnya pembimbingan tesis sebagai bagian dari Tugas Pokok dan Fungsi (TUPOKSI) dosen, dan memiliki loyalitas keguruan (Ruslan, 2016). Sementara itu, Dosen yang baik harus memenuhi tujuh kriteria, yaitu sifat, pengetahuan, apa yang disampaikan, bagaimana mengajar, harapan, reaksi dosen terhadap mahasiswa, dan manajemen.

Dalam hal ini persepsi mahasiswa atas kualitas dosen dalam memberikan bimbingan tesis kepada mereka diharapkan dan ekspektasi yang mereka harapkan dari dosen tersebut dapat mempengaruhi motivasi belajar dan penulisan tesis mereka. Jika seorang dosen sudah memenuhi kriteria dimensi-dimensi kualitas yang mereka harapkan, maka mahasiswa tersebut dapat termotivasi untuk menyelesaikan tesis mereka dengan mereka $(\mathrm{e}-\gg \bullet p)$.

\section{Metode Penelitian}

Penelitian ini merupakan exploratory qualitative research. Creswell dan Miller (2000) menjelaskan bahwa dalam penelitian kualitatif, tujuannya adalah tidak untuk menggeneralisasi ke populasi, tetapi untuk mengembangkan eksplorasi mendalam terhadap inti fenomena. Sehingga jumlah responden dalam penelitian kualitatif umumnya berjumlah relatif lebih sedikit dari penelitian kuantitatif. Responden dalam penelitian adalah mahasiswa yang telah menyelesaikan studi S2 mereka dengan jumlah responden sebanyak 12 orang.

Kualitatif riset diyakini sangat bermanfaat untuk menginvestagi pemahaman tentang pengalaman, tindakan dan kejadian yang dialami oleh individual dan berkaitan dengan prilaku mereka (Pidgeon \& Henwood, 1996). Pendekatan eksploratori lebih lanjut juga dilakukan untuk dapat menemukan lebih jauh informasi yang mendalam tentang persepsi dan ekpektasi mahasiswa secara perorangan, untuk menginvestigasi bagaimana dan mengapa mereka berpikir dan bertindak demikian dan memahami arti dari dimensi-dimensi dosen pembimbing tesis mereka (Ambert, Adler, Adler \& Retzner, 1995).

Para responden adalah mahasiswa Magister Akuntansi yang telah lulus supaya mereka tidak segan ataupun takut dalam memaparkan persepsi dan ekspektasi mereka atas dimensi-dimensi kualitas dosen pembimbing. Jumlah 12 orang responden ini sudah sesuai dengan saran dari para qualitative researcher dunia yang menyatakan bahwa 'some research experts have suggested that a qualitative interview sample should be between 12 and 60' (Adler \& Adler, 2012; Guest, Bunce \& Johnson, 2006). Hal ini dikarenakan pengumpulan data untuk qualitative research menekankan pada in-depth interviews dari para responden, sehingga jumlah responden yang dipilih tidak perlu dalam jumlah yang besar seperti pada quantitative research.

Responden terdiri dari mahasiswa regular dan mahasiswa beasiswa STAR BPKP Magister Akuntansi Fakultas Ekonomi dan Bisnis Universitas Sam Ratulangi supaya dapat mewakili atau merepresentasikan mahasiswa yang sudah bekerja ataupun yang belum bekerja dan mahasiswa yang membiayai kuliahnya sendiri ataupun yang mendapatkan beasiswa studi. 
Metode pengumpulan data yang ditempuh dalam penelitian ini adalah melalui wawancara mendalam (indepth interview), dan dokumentasi (documentation). Lebih spesifik lagi, wawancara yang dilakukan adalah semi-structured interviews.

Wawancara dapat menghasilkan kutipan langsung dari para responden tentang pengalaman, pendapat, perasaan dan pengetahuan mereka (Patton, 2005). In-depth interviews sebagai sebuah tekhnik qualitative research technique dapat mencakup wawancara perorangan dengan sejumlah kecil responden untuk mengeksplorasi persepektif merea tentang ide khusus, program atau situasi (Boyce \& Neale, 2006).

Kombinasi pengumpulan data melalui wawancara dan document analysis dapat mencapai triangulation karena peneliti dapat mengkonfirmasi findings dari sekumpulan data untuk mengurangi potensial bias (Bowen, 2009). Sehingga kedua metode pengumpulan data ini dapat meningkatkan kualitas analisa data (Patton, 1999). Dokumen-dokumen berisi sekumpulan teks atau kata-kata yang dicatat tanpa campur tangan dari peneliti (Bowen, 2009) Dokumen-dokumen tersebut dapat membantu peneliti untuk memahami arti dan menemukan pandangan yang relevan dengan masalah penelitian.

Data interview dianalisa dengan meggunakan analisa isi (content analysis) dan metode inductive analysis dimana tema-tema (themes) muncul dari dalam data bukan dari pola (patterns) yang sudah ditentukan (Cin, 2013). Content analysis adalah metode analisa dokumen untuk menjelaskan tentang fenomena, dan digunakan secara luas dalam penelitian kualitatif di bidang kesehatan, psikologi dan bisnis (Hsieh \& Shannon, 2005). Data kualitatif dapat berupa persepsi tertulis dan tidak tertulis yang ada di benak seseorang (Luna- Reyes \& Anderson, 2003). Qualitative content analysis adalah metode yang paling sering digunakan untuk menganalisa interview transcripts untuk menjelaskan prilaku dan persepsi individu (Yan Zhang \& Wildemuth, 2009). Terlebih lagi, qualitative content analysis dapat digunakan juga untuk menganalisa data teks verbal maupun illustrative yang tidak didapat dari wawancara, tetapi dari artikel, buku dan manuals (Cin, 2013; Hsieh \& Shannon, 2005). Analisa isi dilakukan dengan cara: interview transcript dibaca sedikitnya dua kali, setiap baris kalimat dianalisa untuk mencari arti dan struktur spesifik, struktur naratif tersebut ditandai sebagai subcoding, subcoding yang mirip digabung menjadi coding atau themes, themes diklasifikasikan menjadi katerogori themes dan divalidasi dengan mencantumkan direct quotation dari wawancara responden (Senra, Oliveira, Leal \& Vieira, 2011).

'Themes' yang didapat dari persepsi mahasiswa atas kualitas dosen pembimbing tesis adalah jika dosen pembimbing tersebut:

1. Dosen yang menguasai metode penelitian

2. Dosen senior yang sudah berpengalaman

3. Dosen yang sudah memiliki publikasi internasional

4. Dosen yang menguasai aplikasi komputer

5. Dosen yang menguasai materi/topik tesis

6. Dosen yang dapat mengarahkan mahasiswa

7. Dosen yang teliti

Sedangkan 'themes' atas kualitas dosen pembimbing yang diinginkan oleh mahasiswa adalah:

1. Dosen yang dapat meluangkan waktu yang cukup untuk pembimbingan

2. Dosen yang bisa memiliki kedekatan emosional dengan mahasiswa bimbingannya

3. Dosen yang mampu menjelaskan, mengarahkan dan berkomunikasi dengan efektif

4. Dosen yang mampu membuat penelitian yang berkualitas

\section{Hasil dan Pembahasan}

\section{Findings dan discussions atas Persepsi mahasiswa atas kualitas dosen pembimbing tesis}

Berdasarkan hasil wawancara dengan para responden, kebanyakan para responden menyatakan bahwa dosen pembimbing dikatakan berkualitas jika dosen tersebut menguasai metode penelitian, dosen senior yang sudah berpengalaman, dosen yang sudah memiliki publikasi/jurnal internasional, dosen yang menguasai aplikasi komputer, dosen yang menguasai materi/topik tesis yang dibimbing, dosen yang dapat mengarahkan mahasiswa dan dosen yang memiliki ketelitian dalam membaca atau memeriksa tesis mahasiswa.

Oleh sebab itu, responden menyatakan bahwa tesis mahasiswa jenis kualitatif sebaiknya dibimbing oleh dosen pembimbing yang memiliki keahlian di penelitian kualitatif dan sebaliknya tesis 
mahasiwa jenis kuantitatif dibimbing oleh dosen pembimbing yang memiliki keahlian di penelitian kuantitatif.

Dosen pembimbing itu harus paham tentang metode penelitian...sebaiknya penelitian mahasiswa yang kuantitatif dibimbing oleh dosen kuantitatif dan sebaliknya penelitian kualitatif dibimbing oleh dosen kualitatif..(Responden 2)

Dosen pembimbing tersebut memahami metode penelitian kuantitatif dan kualitatif (Responden 1)

Mahasiswa juga mengatakan bahwa dosen pembimbing tesis tersebut adalah seorang dosen senior yang sudah memiliki pengalaman paling tidak lima (5) tahun sebagai dosen. Hal ini disebabkan dosen tersebut sudah memiliki pengalaman mengajar dan menghadapi para mahasiswa.

Dosen pembimbing tersebut bukan yang baru memiliki pengalaman tetapi sebaiknya sudah 5 tahun menjadi dosen karena semakin lama menjadi dosen semakin banyak pengalaman dosen tersebut mengajar dan menghadapi para mahasiswa (Responden 7)

Responden mahasiswa lainnya mengatakan bahwa dosen pembimbing tesis tersebut sudah memiliki publikasi/jurnal internasional dan menguasai Bahasa Inggris. Hal ini dikarenakan mahasiswa diwajibkan menyadur atau memiliki citation minimal lima (5) buah publikasi internasional untuk penulisan tesis mereka. Sehingga dosen tersebut dapat membaca dan mengerti artikel citation yang tertulis dalam Bahasa Inggris tersebut.

Dosen pembimbing memiliki kemampuan berbahasa asing dan mereka telah mempublikasikan karya ilmiah mereka secara internasional (Responden 10)

Responden mahasiswa yang diwawancarai juga mengatakan bahwa dosen pembimbing tesis tersebut sebaiknya menguasai aplikasi komputer. Lebih lanjut responden tersebut memberikan contoh yaitu dosen menguasai program SPSS untuk penelitian kuantitatif dan NVivo untuk penelitian kualitatif. Selama ini dosen hanya menguasai program Microsoft Word dan Excel, alangkah baiknya mereka memiliki pemahaman tentang aplikasi. Misalnya program SPSS untuk penelitian kuantitatif dan NVivo untuk kualitatif.

Jenis penelitian saya kualitatif dan dosen pembimbing saya tidak menguasai NVivo program untuk penelitian kualitatif saya ini (Responden 4)

Selain kualitas-kualitas tersebut diatas, ada responden yang menginginkan dosen pembimbingnya untuk menguasai materi secara umum dan tema penelitian tesisnya secara khusus. Dosen tersebut diharapkan juga dapat mengarahkan. Yang dimaksud dengan pengarahan adalah dosen pembimbing harus dapat membuat benang merah mulai dai latar belakang hingga kesimpulan. Menariknya, responden ini menyatakan bahwa responden yang bersangkutan tidak mendapatkan pengarahan yang diinginkannya dari dosen pembimbingnya, sebaliknya justru mendapatkan pengarahan tersebut dari dosen penguji. Oleh sebab itu, responden ini menekankan pentingnya pengarahan tersebut.

Dosen pembimbing itu harus menguasai materi secara umum dan tema tesis secara khusus. Dosen tersebut harus membuat benang merah mulai dari latar belakang sampai kesimpulan. Sayangnya saya tidak mendapatkan pengarahan ini dari dosen pembimbing saya, melainkan justru dari dosen penguji saya. Saya baru tahu benang merah tersebut harus ada dalam sebuah tesis dari dosen penguji.

Dosen pembimbing saya tidak membaca tesis saya, hanya ingin langsung menanda tangani persetujuan untuk ujian tesis saja (Responden 8)

Kualitas-kualitas lainnya adalah dosen pembimbing tersebut harus teliti dalam membaca dan memeriksa tesis mahasiswa bimbingannya. Responden mahasiswa mengatakan ada kalanya mereka melakukan kesalahan ketik dan tekhnis pengetikan juga termasuk dalam penilaian kelulusan tesis, sehingga perlu ketelitian dari dosen pembimbing untuk mendapatkan kesalahan ketik tersebut.

Dosen pembimbing sebaiknya mengevaluasi hasil penelitian...apakah hasil penelitian tersebut sudah benar dan memeriksa apakah ada kesalahan ketik..(Responden 5)

Berdasarkan hasil wawancara dengan para responden, kebanyakan para responden menyatakan bahwa dosen pembimbing dikatakan berkualitas jika dosen tersebut menguasai metode penelitian, dosen senior yang sudah berpengalaman, dosen yang sudah memiliki publikasi/jurnal internasional, dosen 
yang menguasai aplikasi komputer, dosen yang menguasai materi/topik tesis yang dibimbing, dosen yang dapat mengarahkan mahasiswa dan dosen yang memiliki ketelitian dalam membaca atau memeriksa tesis mahasiswa.

Kemampuan akademisi yang berkualitas seperti yang diinginkan oleh para mahasiswa tersebut diatas berperan sangat penting dalam meningkatkan kinerja dan keberhasilan mahasiswa yang bersangkutan (Podgursky, Monroe \& Watson, 2004). Kejelasan dalam memberikan pengarahan untuk penulisan tesis mahasiswa terbukti membantu mahasiswa untuk mencapai kualitas tesis yang diinginkan oleh dosen maupun diwajibkan oleh pihak universitas (Metzner, 1989). Kementerian Pendidikan Tinggi, Riset dan Tekhnologi (Kemenristek) menekankan bahwa para dosen harus memiliki publikasi internasional untuk dapat melakukan pengajuan kenaikan pangkat (Kriyantono, 2017). Sehingga dosen harus terlebih dahulu meningkatkan kualitas penguasaan Bahasa Inggris.

Kemajuan tekhnologi saat ini juga harus diperhatikan oleh para dosen. Ertmer dan OttenbreitLeftwich (2014) menyatakan bahwa mindset akademisi saat ini harus dirubah dan akademisi harus menguasai informasi tekhnologi komputer dan mengimplementasikan informasi tekhnologi komputer dalam memfasilitasi pembelajaran para mahasiswanya. Dosen perlu mengupdate kemampuan penguasaan komputer secara lengkap pada dirinya sesuai yang disarankan oleh Krause (2017) bahwa dosen harus dapat mengintegrasikan tekhnologi ke dalam proses belajar mengajar karena hal ini mampu meningkatkan kualitas belajar mengajar secara signifikan.

\section{Findings dan discussions atas Persepsi mahasiswa atas kualitas dosen pembimbing yang diinginkan oleh mereka}

Tema yang didapat dari wawancara terhadap persepsi mahasiswa atas kualitas dosen pembimbing yang diinginkan oleh mahasiswa adalah dosen yang dapat meluangkan waktu yang cukup untuk pembimbingan, dosen yang bisa memiliki kedekatan emosional dengan mahasiswa bimbingannya, dosen yang mampu menjelaskan, mengarahkan dan berkomunikasi dengan efektif dan dosen yang mampu membuat penelitian yang berkualitas.

Seorang responden mahasiswa yang mengalami kendala waktu dalam pembimbingan tesisnya dikarenakan dosen pembimbing tersebut amat sibuk, menginginkan sang dosen untuk dapat meluangkan waktunya untuk memberikan bimbingan. Lebih lanjut lagi, responden ini menekankan bahwa selama ini mahasiswa lebih banyak menghabiskan waktu bimbingan dengan dosen pembimbing 2 daripada dosen pembimbing 1 .

Kesediaan waktu dosen untuk membimbing sangat penting...teman-teman lain sudah beberapa kali bertemu dengan dosen pembimbing 2, untuk saya bisa dihitung dengan jari...dosen pembimbing 2 adalah kunci keberhasilan dari proses pembimbingan...(Responden 12)

Responden lainnya menyatakan dosen pembimbing perlu memiliki kedekatan emosional dengan mahasiswa bimbingannya. Antara dosen dan mahasiswa harus terjalin komunikasi yang baik, mahasiswa dapat bertanya tanpa merasa canggung dan dosen dapat menjawabnya secara lugas. Lebih lanjut lagi, responden ini mengatakan bahwa komunikasi yang terjalin jangan kaku. Dengan banyaknya bertemu dan berkomunikasi diharapkan kedekatan emosional dapat terjalin.

Mahasiswa dan dosen memiliki kedekatan emosional, dimana ada komunikasi yang bagus....saya bertanya tanpa merasa canggung, dosenpun bias menjawab secara lugas..Cara berkomunikasi jangan kaku, jangan jaim, membangun kedekatan..mahasiswa sering bertemu dan berkomunikasi...(Responden 4)

Selanjutnya, responden juga mengatakan bahwa dosen pembimbing itu harus mampu menjelaskan, mengarahkan dan berkomunikasi secara aktif. Hal ini dikarenakan setiap mahasiswa memiliki tingkat kemampuan yang berbeda-beda. Oleh sebab itu, dosen pembimbing harus dapat memberikan masukan-masukan dalam pembuatan penelitian dengan bahasa komunikasi yang santun.

Dosen perlu berkomunikasi secara lebih aktif, sabar dan santun dalam memberikan masukan-masukan karena beberapa mahasiwa berbeda tingkat kemampuan mereka...(Responden 8)

Tema terakhir yang didapat adalah para responden menekankan perlu dosen pembimbing tersebut memiliki kemampuan untuk membuat penelitian yang berkualitas.

Dosen perlu berkomunikasi secara lebih aktif, sabar dan santun dalam memberikan masukan-masukan

karena beberapa mahasiwa berbeda tingkat kemampuan mereka...(Responden 8) 
Keinginan para mahasiswa agar dosen dapat meluangkan waktu untuk dapat memberikan bimbingan adalah sangat masuk akal. Akan tetapi dosen jurusan Akuntansi di Fakultas Ekonomi dan Bisnis saat ini memiliki beban kerja Tri Dharma yang sangat tinggi. Jumlah mahasiswa yang ada tidak sebanding dengan jumlah dosen yang tersedia. Rasio jumlah dosen dan mahasiswa itu berpengaruh signifikan terhadap kualitas belajar dan mengajar. Lebih jauh lagi, dosen mendapatkan gaji yang lebih kecil dibandingkan dengan Pegawai Negeri Sipil (PNS) dengan level yang sama di instansi lainnya. Professor Vedi R Hadiz, seorang akademisi di salah satu universitas di Melbourne, Australia mengatakan bahwa dosen di Indonesia memiliki kewajiban mengajar 20 jam per minggu, sedangkan di Australia hanya berkisar 5 jam per minggu sehingga kuantitas penelitian dosen di Indonesia menjadi sedikit (Tempo.Co, 2016). Untuk itu, Kemenristek Pendidikan Tinggi (DIKTI) perlu merevisi jumlah jam mengajar dosen.

Para responden mahasiswa juga mengharapkan komunikasi yang baik dengan dosen pembimbing. Hal ini sejalan dengan studi yang dilakukan oleh Hui (2005) dan Gecer (2013) yang menyatakan bahwa komunikasi yang efisien antara dosen dan mahasiwa sangat mempengaruhi keberhasilan studi mahasiswa yang bersangkutan. Goodboy (2007) menyatakan bahwa teaching behaviour yang efektif menjadi salah satu penyebab keberhasilan belajar belajar yang dikenal dengan sebutan confirmation. 'Confirmation is (a) expresses recognition of an individual's existence, (b) acknowledges a relationship of affiliation with another individual, (c) expresses awareness of the significance or worth of another individual, and (d) endorses another individual's self-experience'. (Goodboy, 2007:1).

\section{Kesimpulan dan Saran}

Dosen pembimbing tesis dikatakan berkualitas jika dosen tersebut menguasai metode penelitian, dosen senior yang sudah berpengalaman, dosen yang sudah memiliki publikasi/jurnal internasional, dosen yang menguasai aplikasi komputer, dosen yang menguasai materi/topik tesis yang dibimbing, dosen yang dapat mengarahkan mahasiswa dan dosen yang memiliki ketelitian dalam membaca atau memeriksa tesis mahasiswa.

Sedangkan persepsi mahasiswa atas kualitas dosen pembimbing yang diinginkan oleh mahasiswa adalah dosen yang dapat meluangkan waktu yang cukup untuk pembimbingan, dosen yang bisa memiliki kedekatan emosional dengan mahasiswa bimbingannya, dosen yang mampu menjelaskan, mengarahkan dan berkomunikasi dengan efektif dan dosen yang mampu membuat penelitian yang berkualitas.

Berdasarkan kesimpulan diatas, maka diharapkan dosen dapat meningkatkan kemampuan akademisi mereka baik dalam kecakapan keilmuan yaitu penguasaan materi, metode penelitian dan Bahasa Inggris untuk dapat meningkatkan kualitas pembimbingan tesis kepada mahasiswa. Penggunaan Information Computer Technology (ICT) perlu ditingkatkan juga untuk meningkatkan kualitas belajar dan mengajar di era information technology yang berkembang sangat cepat seperti saat ini.

Lebih lanjut lagi, dosen juga harus dapat meluangkan waktu yang cukup untuk melakukan pembimbingan. Akan tetapi, mengingat beban kerja dosen di Indonesia yang sangat tinggi, maka diharapkan Kemenristek dapat merevisi kewajiban para dosen dalam melakukan tugas Tri Dharma dan Tugas Pokok dan Fungsi (TUPOKSI) mereka. Dosen dapat menjalin pula komunikasi aktif dan efisien dengan para mahasiswanya supaya apa yang diharapkan atau diinginkan oleh para mahasiswa maupun dosen dapat disampaikan dan dimengerti dengan baik sehingga tujuan kedua belah pihak dapat dicapai dengan baik.

\section{Daftar Pustaka}

Adler, P. A., \& Adler, P. (2012). How many qualitative interviews is enough? Expert voices and early career reflections on sampling and cases in qualitative research. In S. E. Baker \& R. Edwards (Eds.), (pp. 8-11): National Center for Research Methods, Economic and Social Research Council.

Ambert, A.-M., Adler, P. A., Adler, P., \& Retzner, D. F. (1995). Understanding and Evaluating Qualitative Research. Journal of Marriage and Family, 57(4), 879-893.

Andersen, W., \& Chariri, A. (2012) Analisis Persepsi Mahasiswa Akuntansi dalam memilih profesi sebagai Akuntan (Studi Empiris pada mahasiswa Akuntansi Undip, Unnes, Unissula, Udinus, Unisbank, STIE Totalwin dan Mahasiswa PPA Undip), Disertasi Doktoral, FEB Undip, Semarang Indonesia. 
Borges, A. T., \& Gilbert, J. K. (1999). Mental models of electricity. International Journal of Science Education, 21(1), 95-117.

Bowen, G. A. (2009). Document Analysis as a Qualitative Research Method. Qualitative Research Journal, 9(2), 27-40.

Boyce, C., \& Neale, P. (2006). Conducting In-depth Interviews: A Guide for designing and conducting In-depth interviews for evaluation input. In M. a. E.-. Pathfinder International Tool Series (Ed.).

Cin, M. (2013). Undergraduate students' mental models of hailstone formation. International Journal of Environmental and Science Education, 8(1), 163-174.

Creswell, J. W., \& Miller, D. L. (2000). Determining Validity in Qualitative Inquiry. Theory Into Practice, 39(3), 124-130.

Ertmer, P.A., \& Ottenbreit-Leftwich, A.T. (2014). Teacher Technology Change: How Knowledge, Confidence, Beliefs and Culture Intersect. Journal of Research Technology in Education, 42(3), 255-284.

Gecer, A., 2013. Lecturer-student communication in blended learning environments. Educational Sciences: Theory and Practice, 13(1), 362-367.

Goodboy, A.K. 2007. The Effect of Teacher Confirmation on Student Communication and Learning Outcomes, PhD Thesis, West Virginia University, USA.

Guest, G., Bunce, A., \& Johnson, L. (2006). How many interviews are enough? An Experiment with data saturation and variability. Field Methods, 18(1), 59-82.

Hsieh, F. H., \& Shannon, S. E. (2005). Three Approaches to Qualitative Content Analysis. Qualitative Health Research, 15(9), 1277-1288.

Hui, L., 2005. Chinese cultural schema of education: implications for communication between Chinese students and Australian educators. Issues in educational Research, 15(1), 17-36.

Johnson-Laird, P. N. (1983a). Mental Models, The Foundations of Cognitive Science The MIT Press.

Johnson-Laird, P. N. (1983b). Mental Models, Towards a Cognitive science of language, inference and consciousness (Vol. 6): Harvard University Press.

Krause, J.M. (2017). Physical Education Student Teachers' Technology Integration Self-Efficacy. The Physical Education, 74, 476-496.

Kriyantono, R. (2017) Ikatlah Ilmu dengan Publikasi Internasional, sumber http://sumberdaya.ristekdikti.go.id/index.php/2017/07/21/ikatlah-ilmu-dengan-publikasiinternasional/, diakses pada tanggal 14 Nopember 2017.

Lawler, E.E, \& Suttle, J.L. (1973). Expectancy Theory and Job Behavior, Organizational Behaviour and Human Performance, 9, 482-503.

Luna-Reyes, L. F., \& Anderson, D. L. (2003). Collecting and analysing qualitative data for system dynamics: methods and models. System Dynamics, 19(4), 271-296.

Malan, R., Erwee, R., \& Rose, D. M. (2009). The importance of individual mental models for strategic thinking in organisations. Paper presented at the ANZAM, Melbourne, Australia.

Mao, H., \& Liu, X. (2008). Psychological Contract in the process of enterprises merger, acquisition and integration. Canadian Social Science, 4(1), 22-25.

Metzner, B.S. (1989). Perceived Quality of Academic Advising: The Effect on Freshman Attrition. American Educational Research Journal, 26(3), 422-442.

Patton, M. Q. (1999). Enhancing the quality and credibility of qualitative analysis. Health Service Research, 34(5), 1189-1208.

Patton, M. Q. (2005). Qualitative Research. Encyclopedia of Statistics in Behavioral Science, 3, 16331636.

Pidgeon, N., \& Henwood, K. (1996). Grounded Theory: practical implementation. In J. T. E. Richardson (Ed.), Handbook of Qualitative Research Methods for Psychology and the Social Sciences (pp. 86-101): The British Psychological Society, U.K.

Podgursky, M., Monroe, R., \& Watson, D. (2004). The Academic Quality of Public School Teachers: An Analysis of Entry and Exit Behaviour, Economics of Education Review, 23, 507-518.

Ruslan, R. (2016). Kepuasan Mahasiswa terhadap Kinerja Dosen, Jurnal Ilmu Pendidikan, 17 (3), 230-237.

Senra, H., Oliveira, R. A., Leal, I., \& Vieira, C. (2011). Beyond the body image: a qualitative study on how adults experience lower limb amputation. Clinical Rehabilitation, 26(2), 180-191. 
Tempo.Co. (2016). Ini Penyebab Dosen di Tanah Air kurang suka meneliti, sumber https://nasional.tempo.co/read/831105/ini-penyebab-dosen-di-tanah-air-kurang-sukameneliti, diakses pada tanggal 14 Nopember 2017.

Westbrook, L. (2006). Mental Models: a theoretical overview and preliminary study. Journal of Information Science, 32, 563-579.

Van Eerde, W., \& Thierry, H. (1996). Vroom's Expectancy Models and Work-related Criteria: A Meta Analysis, Journal of Applied Psychology, 81 (5), 575-586. 